\title{
Leadership Satisfaction Structural Model among School Teachers
}

\author{
Muhammad Baqir Abdullah, Foo Chuan Chew, Nik Kamariah Nik Mat", Mokana Muthu Kumarasamy, \\ Kalai Vani Kalimuthu
}

Othman Yeop Abdullah Graduate School of Business, Universiti Utara Malaysia, Sintok, 06010, Malaysia

\begin{abstract}
The purpose of this study is to examine the antecedents of leadership satisfaction among teachers in Malaysian secondary schools. All variables were measured using 7- point interval scale: school leadership satisfaction (6 items) and overall job's satisfaction (4 items) as the endogenous variable, school infrastructure satisfaction (6 items) and satisfaction on teacher's duties (6 items) as exogenous variables. Questionnaires were distributed to 100 teachers based on a random sampling method. The data was input into SPSS 14 and exploratory factor analysis result shows that the school leadership satisfaction and overall job satisfaction were combined as one variable which is named as leadership satisfaction. The data was then analyzed using Structural Equation Modeling (SEM) through AMOS 16. The result shows that the goodness of fit indices of structural equation model are adequate at $\mathrm{GFI}=0.902$, P-Value $=0.349, \mathrm{RMSEA}=0.024$ and ratio $(\mathrm{cmin} / \mathrm{df})=1.056$. The finding supports one significant direct effect in the revised model, thus supporting the hypothesis regarding school infrastructure satisfaction is positively related to leadership satisfaction $(\beta=0.88, \mathrm{cr}=4.404, \mathrm{p}<0.001)$. The result is discussed in the perspective of teacher's satisfaction towards school leadership.
\end{abstract}

Keywords Infrastructure, Teacher'S Duties, Leadership, Overall Job Satisfaction

\section{Introduction}

Job satisfaction is an important element for a person who is working and a good leadership will improve the job satisfaction. School leadership plays an important role to influence teacher's job satisfaction. According to Locke \& Lathan[1], "job satisfaction is a pleasurable or positive emotional state resulting from the appraisal of one's job or job experience and job satisfaction is a result of employee's perception of how well their job provides those things that are viewed as important". Rice et.al[2] state that "job satisfaction can be defined as an overall feeling about one's job or career in terms of specific facets of the job or career". Illardi et.al[3] point out that job satisfaction is a "positive work attitudes, cognitive or affective evaluation of work which has considerable implications for employee psycholo gical and physical wellbeing".

According to Roger[4], a leader is a person who"calculated risks when required, speak out against the status quo, step forward to take responsibility and show initiative when needed". "Leadership is a process whereby an individual influences a group of individuals to achieve a common goal"[5]. Jackson et.al[6] state, "leadership is like

\footnotetext{
* Corresponding author:

drnikuum@gmail.com (Nik Kamariah Nik Mat)

Published online at http://journal.sapub.org/economics

Copyright (C) 2012 Scientific \& Academic Publishing. All Rights Reserved
}

beauty- it is difficult to describe, but we certainly know it when we experience it".

Recently, the Prime Minister of Malaysia had announced the increment on public servant salary especially for teachers in 2012 budget to increase their job satisfaction. This shows that satisfaction is an important element to determine the quality of education. Zaiton Mohamad[7] had done a research on the teacher's satisfaction in three schools in Pahang, Malaysia to find out how far the Malaysian's teachers are satisfied with their school leadership through school's infrastructure satisfaction and teacher's duty satisfaction.

Thus, the objective of this study is to examine the antecedents of leadership satisfaction among teachers in Malaysian secondary school and to examine the relation between school leadership satisfaction with satisfaction on teacher's duties and school infrastructure satisfaction. This paper is structured as follows. First, we review the literature of school infrastructure, satisfaction towards leadership satisfaction and also the satisfaction on teacher's duties towards leadership satisfaction. Next, we present the research methods, analysis and findings. Finally, the results were discussed in terms of its contribution to the upgrading of teacher's job satisfaction towards leadership in school and recommendations for future research.

\section{Literature Review}

\subsection{Job Satisfaction and Infrastructure Satisfaction}


Steve, D. and Catherine[8] who did a research on the job satisfaction using ten factor model found out that infrastructure do effect the job satisfaction at $\beta=0.67$.[9] found that the existing of correlations between the quality of the physical environment, teacher satisfaction, and student behaviour. His results of these analyses support the findings of previous studies regarding the relationship of student behavior and the quality of the physical environment of the school to teacher satisfaction[10],[11],[12],[13],[14] \&[15]. Mei-yung Leung et.al[16], who done a research on the impact of school facilities on working behaviour of teachers found that the teacher's satisfaction on infrastructure depend on the types of infrastructure that was provided by school. Ibrayim[17], found that this study provided evidence regarding the effects of facility conditions on the delivery of instruction in public schools.

\subsection{Job Satisfaction and Teacher's Duties Satisfaction}

Liaquat et.al[18], reported that the correlation value between the job satisfaction and teaching behavior was 0.789 . This is a very strong correlation. The conclusion is that there is a strong relationship between the job satisfaction and teaching behavior. This result also supported by another researcher,[19]. Wei et.al[20], find out that Black Americans Teachers who persisted in pursuing teaching careers since high school were significantly more satisfied than those who did not persist Whereas socioeconomic status and mother being a teacher positively predicted teachers' job satisfaction, the parental educational attainment negatively predicted the job satisfaction of teachers. Gian et.al[21], did research in teachers' personal efficacy beliefs affected their job satisfaction and students' academic achievement Lee \& Kamarul[22], find that employee performance was found to be significantly and positively correlated to job satisfaction.

\subsection{Job Satisfaction and Leadership Satisfaction}

Kylie \& Brett[23], find that job satisfaction would relate to leadership behavior was supported. Pearson's correlations indicated significant positive relationships between co-workers satisfaction, supervision satisfaction, initiating structure and consideration leadership behavior, with the exception co-workers satisfaction and consideration leadership behaviour Lee \& Kamarul[22], find that leadership behaviors did not affect employee performance significantly, but significantly affected job satisfaction negatively. Beatrice et.al[24], find that a relatively strong relationship was found between leadership quality and job satisfaction $(b=0.32$, $\mathrm{p}(0.001)$.

\subsection{Underpinning Theory}

Herzberg et.al[25] performed studied to determine which factor in an employee's work environment caused satisfaction or dissatisfaction. He used two factor theories (Herzberg's Motivation-Hygiene Theory). Herzberg found that the factors causing job satisfaction (and presumably motivation) were different from that causing job dissatisfaction. Herzberg suggested that job satisfaction and job dissatisfaction are caused by different and independent set of factors. He found that people are satisfied, they attribute their satisfaction to the work itself, while when people are dissatisfied with their jobs, and they are concerned about the environment in which they work.

Therefore, we can say that job satisfaction is caused, on the one hand, by a set of factors related to work itself, such as nature of job, achievement of work, possibilities of personal growth and recognition, and promotion opportunities. These factors are called motivators by Herzberg, as they should motivate people to higher performances.

On the other hand, job dissatisfaction is a result of "conditions that surround the doing of the job", such as (physical) working condition, salary, company policies, job security, quality of supervision, and relations other. Herzberg called these as a hygiene factors (or maintenance) factors.

For this study, leadership and infrastructure are leading to dissatisfaction while teacher's duties are leading to satisfaction in the factor affecting job attitudes. The overall job satisfaction is depending on all the factors that affecting job attitude.

\section{Method}

In this study, 200 questionnaires were distributed and we managed to receive 100 responses. The SEM was employed to path analysis. From the hypothesized model, refer to Figure 1, there were two regression coefficients: (1) independent variables are school infrastructure satisfaction and school teacher's duty satisfaction; and dependent variable is school leadership satisfaction and overall job satisfaction.

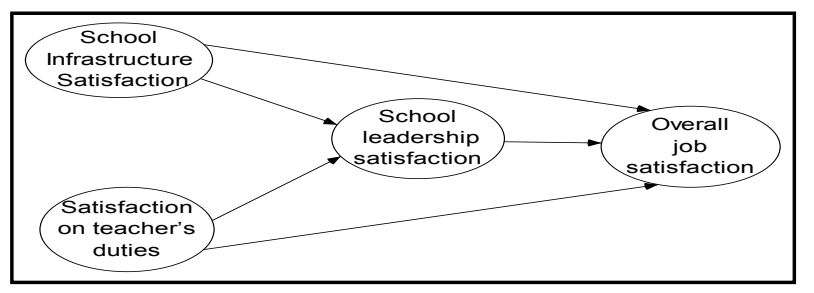

Figure 1. Research Framework

Each variables was measured as follows: the variables teacher's duty satisfaction was adopted from[26] and[27], (6 items measured by 5-point interval-scale of (1)-most unsatisfied to (5)-most satisfied); school infrastructure satisfaction was adopted from[28] - (6 items measured by 5 -point interval-scale of (1)- most unsatisfied to (5)-most satisfied); school leadership satisfaction was adopted from[28] - (6 items measured by 5-point interval-scale of (1)- most unsatisfied to (5)-most satisfied); overall job satisfaction was adopted from[29];[30];[31] - (4 items measured by 5 -point interval-scale of (1)- most unsatisfied to (5)-most satisfied). There are also five demographic questions included in the instrument which use ordinal and 
nominal scale such as gender, age, marital status, race and length of job experience.

The respondent's for this study ages ranged from twenty-one years old to fifty-eight years old. Only $1 \%$ of the respondent's ages are below twenty-five. Followed by $12 \%$ of respondent's ages are twenty-six to thirty-three. Then follow by $28 \%$ of respondent's age in the range of thirty-four to forty-one. Most of the respondents are in the age limit of forty-two to forty-nine years old which is $32 \%$. The respondent's age above fifty years old is $27 \%$. The sample size was randomly selected and consisted of both male $(43.4 \%)$ and female $(56.6 \%)$ teachers. Most of them had married $(72.7 \%)$. The racial compositions are Malay (35.4\%), Chinese $(62.6 \%)$ and Indian (2.0\%). The most important things in measuring the job satisfaction are the length of teaching. The length of teaching is divided into three levels in this study. $41 \%$ of the respondent's is in the first level which is one year to twelve years. Followed by $36 \%$ of the respondent's length of teaching are thirteen to twenty-four years. $23 \%$ of the respondent's is in the third level with the length of teaching from twenty-five to thirty-six years

Table 1. Cronbach's Alpha and Composite Reliability

\begin{tabular}{|c|c|c|c|}
\hline Variables & $\alpha$ & & $\mathrm{CR}$ \\
\hline Leadership & 0.882 & Infrastructure & 0.81605792 \\
\hline Infrastructure & 0.835 & $\begin{array}{l}\text { Teacher's } \\
\text { Duty }\end{array}$ & 0.84534631 \\
\hline $\begin{array}{c}\text { Teacher's } \\
\text { Duty }\end{array}$ & 0.863 & $\begin{array}{c}\text { Overall } \\
\text { leadership } \\
\text { satisfaction }\end{array}$ & 0.34997713 \\
\hline Overall & 0.843 & & \\
\hline
\end{tabular}

\section{Results}

A hypothesized model based on the literature was used to analyze how leadership influenced school infrastructure satisfaction and teacher's school duty satisfaction. The goodness of fit of the model, our hypothesized model did not adequately fit to the empirical data (Chi-squares $=400.256$, $d f=207$, Ratio=1.934, $\mathrm{p}<.01$, GFI $=.732$, RMSEA $=.098$ ). The data was input into SPSS 14 and exploratory factor analysis result shows that the school leadership satisfaction and overall job satisfaction were combined as one variable which is named as leadership satisfaction. The data was then analyzed using SEM through AMOS 16.

Therefore, we adjusted the model based on[7] in this study. The result showed a good fit between the adjusted model and the empirical data given by the sample group (Chi-squares $=78.128, d f=74$, Ratio=1.056, $\mathrm{p}<.349$, GFI $=$. 902, RMSEA=.024). The result from the adjusted model were able to specify the path coefficient of exogenous variables, which were defined as the causal factors of school infrastructure satisfaction and teacher's duty satisfaction presented in Figure 2.

As shown in above diagram, the school infrastructure and school overall leadership satisfaction was found to be a significant variable at $<0.0024$. While, standard error and critical ratio for school infrastructure variable respectively are 0.201 and 4.404 .

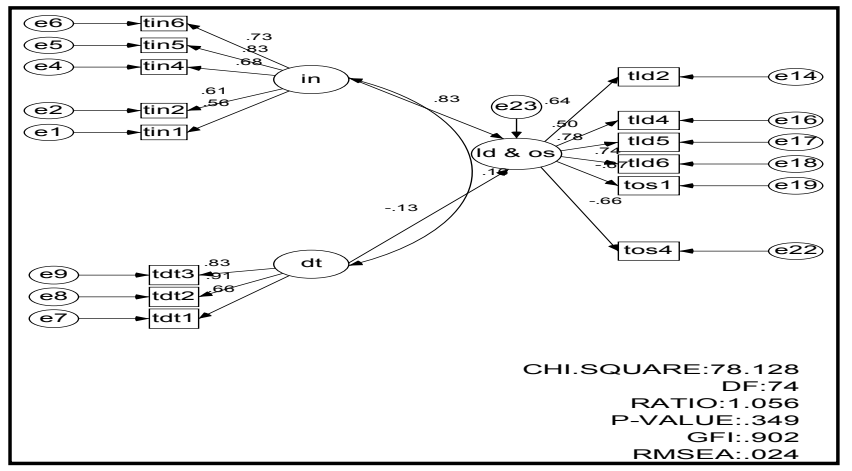

Figure 2. Revised Model

There are only have result of the total effect and direct effect of the relationship between variables in the adjusted model supported only one hypothesis. Moreover, to adjust for the model fit, we get a direct path coefficient of school infrastructure satisfaction to school leadership satisfaction. The result revealed that school leadership satisfaction was directly predicted by perceived school infrastructural satisfaction and teacher's duty satisfaction $(\beta=0.83$ and -0.13 , respectively). These variables could account for $68.89 \%$ of the variance in school leadership satisfaction.

Cronbach's Alpha and Composite Reliability (CR) was used to find out the validity. Cronbach's Alpha measures the internal consistency of variables measuring the construct in a summated scale; composite reliability offers a more retrospective approach in overall consistency of the construct itself. While the composite reliability measures the reliability of a construct in the measurement model. The calculation of composite reliability takes the error into consideration. At the beginning the value of Cronbach's Alpha for 4 item of overall job satisfaction is 0.412 and after excluded one item the value of overall job satisfaction $(\alpha=0.843)$. Then, the result depicted that the value Cronbach's Alpha value for the all variables is valid (after invalid items excluded) for school leadership satisfaction $(\alpha=0.882)$, school infrastructure satisfaction $(\alpha=0.835)$, and teacher's duty satisfaction $(\alpha=0.863)$, which means that the instrument has a high level of consistency (above 0.8 ). The composite reliability is acceptable if more than 0.6 but the composite reliability for overall job satisfaction is only 0.3499713 .

\section{Conclusions}

This study has established two direct causal effects: (1) school infrastructure satisfaction and overall leadership satisfaction; and (2) teacher's duty satisfaction and overall leadership satisfaction. Interestingly, we found that the factor loading of infrastructure satisfaction show a significant effect with school overall leadership; while there is no effect between the teacher's duties and overall leadership satisfaction. The first effect was supported by previous study 
but only some of previous study supported the second effect. It is because the items of the variable influenced the results of the variable.

\section{ACKNOWLEDGEMENTS}

We would like to thank Foo Chuan Chew, Prof Nik Kamariah, Kalai, Mokana, Juzaimy, Umie Kartina, Rabiatul and Fitriah for their helpful comments and assistance on an earlier version of this paper.

\section{REFERENCES}

[1] Locke, E.A. \& Lathan, G.P., "Theory of goal setting and task performance", Englewood Cliffs, N.J.: Prentice-Hall. 1990.

[2] Rice, R. W., Gentile, D. A., and McFarlin, "Facet importance and job satisfaction", Journal of Applied Psychology, vol. 76, pp. 31-39, 1991.

[3] Illardi, B.C., Leone, D., Kasser, T., \& Ryan, M., "Employee and supervisors ratings of motivation: main effects and discrepancies associated with job satisfaction and adjustment in a factory setting", Journal of Applied Social Psychology, vol. 23, 1993.

[4] Roger, H. "Time for leadership development interventions in the public health nutrition workforce", Public Health Nutrition, vol. 12, no. 8, 2009.

[5] Kristina G. R., "Leadership vs. Management. Community and Leadership Development," 2009.

[6] Jackson, B. and Parry, K., A Short, Fairly Interesting and Reasonably Cheap Book about Studying Leadership, Sage, London, 2008.

[7] Zaiton Mohamad, "Kepuasan Kerja Guru-Guru di Tiga Sekolah di Pahang", Jabatan Psikologi, Universiti Kebangsaan Malaysia, Selangor, 1982.

[8] Steve, D. and Catherine, S., "Moving into the third, outer domain of teacher satisfaction", Journal of Educational Administration, vol. 38, no. 4, 2000.

[9] Roy. F. M. JR., "The relationships among school facility characteristics, student achievement, and job satisfaction levels among teacher," 2003.

[10] Brouwers, A., \& Tomi'c, W, "Teacher burnout, perceived self-efficacy in classroom management, and student disruptive behavior in secondary education. Curriculum and Teaching", vol.14, no.2,pp 7-26, 1999.

[11] Byrne, B. M., "Investigating causal links to burnout for elementary, intermediate, and secondary teachers." Paper presented at the annual meeting of the American Educational Research Association, San Francisco, CA, 1992.

[12] Richard M. Ingersoll, "Teacher Turnover and Teacher shortages: An Organization analysis.” American educational Research Journal, vol. 3, no. 38, pp. 499-534, (2001).

[13] Kyriacou. C., "Teacher stress and burnout : An International review." Education Research. Vol. 29, no. 2, pp. 146-152, 1987.

[14] Ostendorf, F., "Measuring interpersonal behavior with the German Interpersonal Adjective Scales. In R. Riemann, F. M. Spinath \& F. Ostendorf (Eds.), Personality and temperament. Genetics, evolution, and structure" Lengerich, pp. 232-260, 2001.

[15] Stenlund, K. Vern. "Teacher Perceptions Across Cultures: The Impact of Students on Teacher Enthusiasm and Discouragement in a Cross-Cultural Context." The Alberta Journal of Educational Research, vol. 41, no. 2, p. 145-161, 1995.

[16] Mei - yung Leung, John K.W. Chan \& Zhaohong Wang, "Impact of school facilities on working behavior of teachers", International Journal of Strategic Property Management, vol. 10, no. 2, pp. 79-91, 2006.

[17] Ibrayim. D., "Relationship between school facility conditions and the delivery of instruction. Evidence from a national survey of school principals", Journal of Facilities Management, vol. 1, no. 8, pp. 8-25, 2010.

[18] Liaquat. H., Muhammad. A. K. A., \& Khuda B. M., "Relationship between the job satisfactions of elementary school teachers with their teaching behavior", Interdisciplinary Journal of Contemporary Research in Business, vol. 3, no. 1, 2011.

[19] Sergiovanni, T., "Factors which affect satisfaction and dissatisfaction of teachers", The Journal of Educational Administration, vol. 5, no. 1, pp. 66-81, 1967.

[20] Wei. C. J. M., Randy, E., \& Donna H., "Job satisfaction and career persistence of beginning teachers"International Journal of Educational Management. vol. 1, no. 22, pp. 48-61, 2008.

[21] Gian. V. C., Claudio. B., Patrizia. S., \& Patrick. S. Malone, "Teachers' self-efficacy beliefs as determinants of job satisfaction and students' academic achievement: A study at the school level", Journal of School Psychology, no. 44, pp. 473-490, 2006.

[22] Lee. H. Y., \& Kamarul. Z. B. A., "The moderating effects of organizational culture on the relationships between leadership behavior and organizational commitment and between organizational commitment and job satisfaction and performance", Leadership \& Organization Development Journal, vol. 1, no. 30, pp. 53-86, 2009.

[23] Kylie. B., \& Brett. F., "Leadership and job satisfaction among aviation fire fighters in Australia", Journal of Managerial psychology. vol. 1, no. 15, pp. 87-97, 2000.

[24] Beatrice. I. J. M., Karen. V. D., \& Hans. M. H, "Intention to leave nursing. The importance of interpersonal work context, work-home interference, and job satisfaction beyond the effect of occupational commitment", Career Development International, vol.7, no. 14, pp. 616-635, 2009.

[25] Herzberg, F., Mausner, B., Peterson, R., \& Capwell, D., "Job attitudes: Review of research and opinion. Pittsburg", Psychological Service of Pittsburg, 1959.

[26] Caprara, G. V., Barbaranelli, C., Borgogni, L., Petitta, L., \& Rubinacci, A, "Teachers' school staff's and parents' efficacy beliefs as determinants of attitude toward school", European Journal of Psychology of Education, vol. 18, pp. 15-31, 2003. 
[27] Caprara, G. V., Barbaranelli, C., Borgogni, L., \& Steca, P, "Efficacy beliefs as determinants of teachers' job satisfaction", Journal of Educational Psychology, vol. 95, pp. 821-832, 2003.

[28] Online Available: www.edfacilities.org/pubs/index.cfm

[29] Patterson and Spreng, "Modelling the relationship between perceived value,satisfaction and repurchase intentions in a business-to-business,services context:an empirical examination", International Journal of Service Industry Management, vol. 1.8, no. 5, pp. 414-434, 1997.
[30] Bloemer, J., Ruyter, K.D., Peeters, P, "Investigating drivers of bank loyalty: the complex relationship between image, service quality and satisfaction", International Journal of Bank Marketing, vol. 16, no. 7, pp. 276 - 86. 1998.

[31] Caruana, A. "Service loyalty: the effects of service quality and the mediating role of customer satisfaction", European Journal of Marketing, vol. 36, no. 7/8, pp. 811 